ZOOLOGIA 27 (6): 973-978, December, 2010

doi: $10.1590 /$ S1984-46702010000600020

\title{
Does gestation or feeding affect the body temperature of the golden lancehead, Bothrops insularis (Squamata: Viperidae) under field conditions?
}

\author{
Rafael P. Bovo ${ }^{1,3}$; Otavio A. V. Marques $^{2}$ \& Denis V. Andrade ${ }^{1}$ \\ 1 Instituto Nacional de Ciência e Tecnologia em Fisiologia Comparada, Departamento de Zoologia, Instituto de Biociências, \\ Universidade Estadual Paulista. Caixa Postal 199, 13506-900 Rio Claro, SP, Brazil. \\ ${ }^{2}$ Laboratório de Ecologia e Evolução, Instituto Butantan. 05503-900 São Paulo, SP, Brazil. \\ ${ }^{3}$ Corresponding author. E-mail: rpbovo@yahoo.com.br
}

\begin{abstract}
Temperature affects physiological performance in reptiles and, therefore, body temperature $\left(T_{b}\right)$ control is argued to have an important adaptive value. Alterations in $T_{b}$ due to transient changes in physiological state, as during digestion or gestation, are often linked to the potential benefits of a more precise $T_{b}$ regulation. However, such thermoregulatory responses in nature remain controversial, particularly for tropical snakes. Herein, we measured $T_{b}$ of the golden lanceheads, Bothrops insularis (Amaral, 1921), at Queimada Grande Island, southeastern Brazil, to test for alteration in selected body temperatures associated with feeding or gestation. We found no evidence that postprandial or gravid snakes selected for higher $\mathrm{T}_{\mathrm{b}}$ indicating that, under natural conditions, body temperature regulation in $B$. insularis apparently encompasses other ecological factors beyond physiological state per se.
\end{abstract}

KEY WORDS. Digestion; gravid females; postprandial thermophilic response; snake; thermoregulation; Neotropics.

Ectothermic organisms such as snakes are particularly sensitive to changes in environmental temperature since they depend mainly on external heat resources for the regulation of body temperature $\left(\mathrm{T}_{\mathrm{b}}\right)$. Metabolic heat production in snakes, except in a few particular situations (HutCHISON et al. 1966, VAN Mierop \& Barnard 1976, Marcellini \& Peters 1982, Tattersall et al. 2004), is so low that its contribution to the control of $T_{b}$ is usually negligible (RUBen 1976). Moreover, a snake's $T_{b}$ will mainly be determined by the use of thermal features available in the environment at any given time (Peterson et al. 1993). Body temperature can be changed during the performance of different activities. Because physiological performances may have distinctly different thermal optima, snakes are able to improve their performance for a given activity by temporarily changing their preferred $\mathrm{T}_{\mathrm{b}}$ (STEVEnson et al. 1985, VAN Damme et al. 1991). Well-known examples of such plasticity is the increase in $\mathrm{T}_{\mathrm{b}}$ following the ingestion of food (REgaL 1966, SieverT \& Andreadis 1999, Blouin-Demers \& Weatherhead 2001a), referred to as the postprandial thermophilic response, and the maintenance of higher and less variable body temperatures by gravid females (Charland \& Gregory 1990, Brown \& Weatherhead 2000, Blouin-Demers \& Weatherhead 2001b).

Digestion in snakes may last for many days (BENEDICT 1932, ANDRADE et al. 1997, WANG et al. 2001) causing impaired capacity for locomotion (Garland \& Arnold 1983, Ford \& Shuttlesworth 1986), which may constrain their ability to defend themselves against predators or engage in other ecologically relevant activities. Thus, an increase in the rate of meal digestion by the elevation of $T_{b}$ (i.e. postprandial thermophilic response) is largely accepted as beneficial for snakes (Lillywhite 1987, Reinert 1993, Sievert \& Andreadis 1999, Wang et al. 2002). This, indeed, seems to be the case since such responses are commonly found when snakes are tested in thermal gradients, where temperature is the sole variable being manipulated (Regal 1966, Lysenko \& GiLLIS 1980, Touzeau \& Sievert 1993). During gestation, which represents an even longer commitment to an altered physiological state than feeding, the maintenance of adequate $T_{b}$ is even more crucial than during digestion because failure in this case may compromise embryo development, with direct negative consequences to reproductive success (Fox et al. 1961, ANDRADE \& ABE 1998). However, despite the importance of temperature in both cases, changes in selected $\mathrm{T}_{\mathrm{b}}$ due to digestion or gestation have been rarely documented under field conditions for snakes, particularly in the Neotropics.

Here we report on the effects of feeding and gestation on $\mathrm{T}_{\mathrm{b}}$ of the golden lancehead, Bothrops insularis (Amaral, 1921), sampled under field conditions in a subtropical region of the South America. The golden lancehead is a critically endangered endemic (MARQues et al. 2004) pitviper from Queimada Grande Island (QGI), located $33 \mathrm{~km}$ off the coast of southeast Brazil $\left(24^{\circ} 29^{\prime} \mathrm{S}, 46^{\circ} 40^{\prime} \mathrm{W}\right)$, with a total area of $0.43 \mathrm{~km}^{2}$. A population of approximately 2,500 individuals dwells within the lowland 
forest that covers about $55 \%$ of the island (MARTINs et al. 2008). The high density of snakes and the limited area of QGI offer a unique opportunity for the gathering of biological data under field conditions. The data presented here were collected within a broader research program devoted to the study and conservation of the species (see www.jararacailhoa.org). Specifically, we tested the prediction that, in nature, gravid and postprandial individuals of $B$. insularis would exhibit higher body temperatures than non-gravid females and fasting specimens, respectively.

\section{MATERIAL AND METHODS}

Field work was carried out during regular visits to QGI during the years of 2007-2008. Excursions typically lasted for 3-5 days and were planned to sample snakes during all seasons. Air temperature and humidity from an open area at QGI were sampled continuously by a meteorological station (HOBOware ${ }^{\circledR} 2.2$, Onset Computer Co.) installed at the site. Climate at QGI can be classified as wet tropical "Af" type, according to Köppen-Geiger's system (Peel et al. 2007). Average air temperature measured during the study period was around $27^{\circ} \mathrm{C}\left(21-38^{\circ} \mathrm{C}\right.$, min-max) during the hottest month (March), and around $18^{\circ} \mathrm{C}\left(15-27^{\circ} \mathrm{C}\right.$, min-max) during the coldest month (August). The average monthly relative humidity was always higher than $90 \%$.

Snakes were searched for along a main transect $(\sim 1500 \mathrm{~m})$ at different times of the day. Upon capture, cloacal $\mathrm{T}_{\mathrm{b}}$ was measured within 30 secs with a quick response temperature probe sensor (ETI - EcoTemp model; $\pm 1 \%$ precision and $0.1^{\circ} \mathrm{C}$ resolution) inserted into the snake's cloaca. Snout-vent-length (SVL), body mass, reproductive stage, posture, time of the day, height of substrate, and activity (ambushing, moving or resting) were also recorded. Female snakes were carefully examined by palpation and were classified as gravid if they were found bearing embryos. Postprandial individuals were induced to regurgitate the stomach contents and, if the prey itens maintained structural integrity, i.e. with the body wall not ruptured, we considered that ingestion had occurred within the previous 48 hours (see AndRADE et al. 1997), and these snakes were classified as postprandial.

Operative environmental temperatures $\left(\mathrm{T}_{\mathrm{e}}\right)$ was sampled using copper "snake" models $(\mathrm{n}=6)$ filled with water and painted to match the colour of golden lanceheads (see BRown \& WeATHERHEAD 2000, Row \& Blouin-Demers 2006). Models were distributed at random across QGI in order to sample the possible thermal habitats used by the snakes (e.g. open and forested areas, different altitudinal gradients on the vegetation, and retreat sites; see MARTins et al. 2008 for details about habitats available at the QGI). Temperature of the models were recorded continuously throughout the study period once every 16 min using temperature dataloggers (StowAway ${ }^{\circledR}$, TidBit $^{\circledR}$ ) placed inside of them (resulting in 5760 values for $\mathrm{T}_{\mathrm{e}}$ ). The thermal accuracy of the models was determined against fresh snake carcasses under a variety of conditions (rainy, sunny, day, night) and in all cases they agreed with the snake's thermal properties with great accuracy (Pearson linear regression; snake carcass $=-0.035+(0.99$ * $\mathrm{T}_{\mathrm{e}}$ model); $\left.\mathrm{r}^{2}=0.973 ; \mathrm{F}_{1,90}=3205.9 ; \mathrm{p}<0,001\right)$.

To check whether body temperature of gravid or postprandial snakes was significantly different from the rest of the population, we constructed a "null model" by fitting a linear regression (minimum square method) between $\mathrm{T}_{\mathrm{b}}$ and $\mathrm{T}_{\mathrm{e}}$ for all non-gravid females $(n=28)$ and fasting individuals $(n=33)$ found at the same season (see details below). In this regression, $\mathrm{T}_{\mathrm{e}}$ values were taken from the physical model located at the most similar habitat to where the snake was found and at the same time ( $\pm 16 \mathrm{~min}$, due to the sampling interval) for which $\mathrm{T}_{\mathrm{b}}$ was recorded. We then checked whether $\mathrm{T}_{\mathrm{b}}$ of gravid or postprandial snakes would fit within the $95 \%$ confidence interval calculated for the general relationship between $\mathrm{T}_{\mathrm{b}}$ and $\mathrm{T}_{\mathrm{e}}$ for the non-gravid and fasting snakes. Afterward, we performed a Student's t-test on the calculated residuals for the regression line comparing postprandial $v s$. fasting individuals within the appropriate season to test whether differences in $\mathrm{T}_{\mathrm{b}}$ would occur independently of $\mathrm{T}_{\mathrm{e}}$. Finally, we selected fasting $(\mathrm{n}=9)$ and non-gravid females $(\mathrm{n}=5)$ with similar body size and whose $\mathrm{T}_{\mathrm{b}}$ was recorded under conditions (microhabitat, posture, daytime, season, and $\mathrm{T}_{\mathrm{e}}$ ) identical to the postprandial and gravid snakes, respectively, and tested for significant differences in $\mathrm{T}_{\mathrm{b}}$ using a Student's t-test. Whenever necessary, to adhere to assumptions of normality and homoscedascity, data were $\log _{10}$ transformed before statistical analysis. All statistical procedures were applied according to ZAR (1996) using the SigmaStat statistical software (SSI, Richmond, CA, USA). Unless specified otherwise, all values are presented as mean $\pm \mathrm{SE}$, and differences were accepted as statistically significant when $\mathrm{p} \leqslant 0.05$.

\section{RESULTS}

We found nine individuals of the golden lancehead that had recently eaten (Tab. I). From all of them, we recovered the ingested prey and found that they had eaten, in all cases, the seasonal migrant bird (Passeriformes) Elaenia chilensis Hellmayr, 1927 (average meal mass equal to $18 \%$ of the snake body mass). All postprandial snakes were found during the summer (February/March) within the forested area, as previously observed (MARTins et al. 2008). None of the postprandial individuals were found to deviate significantly from the general relationship between $T_{b}$ and $T_{e}$ for the season (Fig. 1) (i.e., all of their $T_{b}$ values felt within the $95 \%$ confidence interval for the regression). Corroborating this, the test on the residual values for this regression did not show any significant difference between postprandial and fasting snakes (Student's t-test, $\mathrm{t}_{36}=-1.65$, $\mathrm{p}=0.11$ ). Finally, the direct comparison between postprandial and fasting individuals, recorded under similar conditions, also revealed no significant difference in $\mathrm{T}_{\mathrm{b}}$ (Student's t-test, $\mathrm{t}_{16}=0.2$, $\mathrm{p}=0.84 ;$ Fig. 3). 

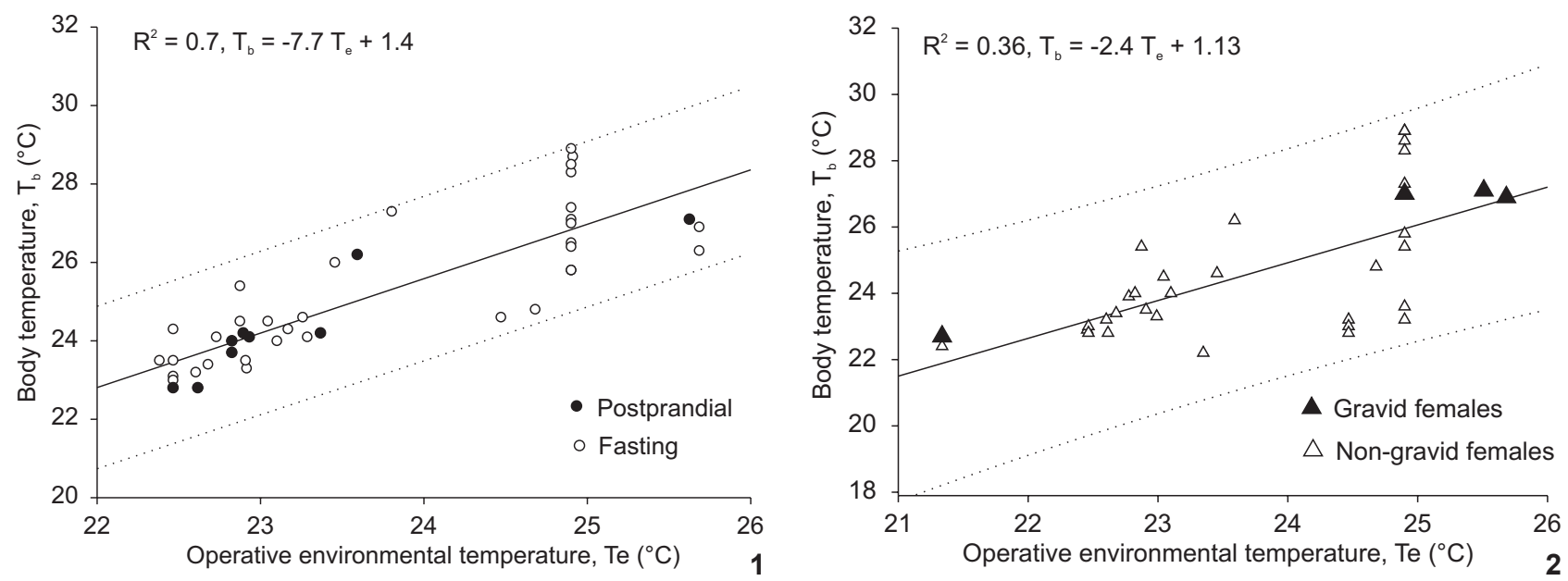

Figures 1-2. Least square regression lines (solid) and $95 \%$ prediction intervals (dotted) for the relationship between body temperature and operative environmental temperature (of the same microenvironment where each snake was found) for free-ranging golden lanceheads, B. insularis. (1) Open and solid circles in indicate fasting $(n=33)$ and postprandial $(n=9)$ snakes, respectively (all individuals found during summer). (2) Open and solid triangles in indicate non-gravid $(n=33)$ and gravid $(n=4)$ females, respectively (sampled during spring/summer). Notice that body temperature values of postprandial and gravid individuals always fell within the $95 \%$ confidence intervals for the respective season.

Four gravid females of the golden lancehead, all of them found in the forested area, had their $T_{b}$ sampled (Tab. I). Two of them were found in late spring (December) and contained four and five embryos, whereas the other two were found in late summer (March) and contained four embryos each. In none of these cases did body temperature deviate from the general relationship between $T_{b}$ and $T_{e}$ for the two seasons combined (Fig. 2) or for each of them considered separately (not shown). The comparison between $\mathrm{T}_{\mathrm{b}}$ values recorded for gravid snakes compared to those recorded for non-gravid females, found under similar conditions, did not reveal a significant difference (Student's t-test, $t_{7}=-0.02, p=0.98$, see Tab. I and Fig. 3 ).

Fasting snakes included adult male and females, the nongravid group included only adult females. For all groups the most common posture was coiled with the head lying over the body in an apparent alert/ambushing posture (OLIVEIRA \& MARTINS 2001).

\section{DISCUSSION}

Mean body temperature for postprandial snakes fit the general relationship observed between $\mathrm{T}_{\mathrm{b}}$ and $\mathrm{T}_{\mathrm{e}}$ for fasting snakes indicating that $B$. insularis did not modify its thermoregulatory behaviour during digestion. The absence of differences between fed and fasting snakes also indicates that heat conductance was not altered (by postural changes, for example) and/or by postprandial thermogenesis (see TATTERSALl et al. 2004). Corroborating these findings, the residual analysis and the direct comparison of postprandial and fasting individuals (under similar conditions) also failed to identify any significant difference in $T_{b}$ that could be attributed to a postprandial thermophilic response. Indeed, $\mathrm{T}_{\mathrm{b}}$ values for postprandial and fasting snakes were found to completely overlap each other (Fig. 3).

One possible explanation for the lack of a postprandial thermophilic response in B. insularis may be related to micro-

Table I. Body temperature of free-ranging golden lanceheads, B. insularis. Gravid and postprandial individuals were compared to nongravid females and fasting specimens, respectively, found under similar conditions. No significant difference was found for any of the pairwised comparisons (Student's t-test, see text for details). Mean \pm Standard Error.

\begin{tabular}{lcccc}
\hline \multicolumn{1}{c}{ Variable } & Postprandial & Fasting & Gravid females & Non-gravid females \\
\hline Body Mass $(\mathrm{g})$ & $99.8 \pm 16.3$ & $103.2 \pm 15.9$ & $205.6 \pm 12.8$ & $191.8 \pm 13.7$ \\
Snout-vent-length $(\mathrm{mm})$ & $633.7 \pm 23.3$ & $624.4 \pm 27.7$ & $742.6 \pm 26.3$ & $805.0 \pm 28.2$ \\
Body temperature, $\mathrm{Tb}\left({ }^{\circ} \mathrm{C}\right)$ & $24.3 \pm 0.4$ & $24.2 \pm 0.3$ & $25.9 \pm 1.0$ & $25.9 \pm 1.1$ \\
Operative Environmental Temperature, $\mathrm{Te}\left({ }^{\circ} \mathrm{C}\right)$ & $23.2 \pm 0.3$ & $23.4 \pm 0.5$ & $24.3 \pm 1$ & $24.2 \pm 0.7$ \\
$\mathrm{n}$ & 9 & 9 & 4 & 5 \\
\hline
\end{tabular}


habitat use. Golden lanceheads are strict forest dwellers rarely venturing in open areas or forest edge zones to bask (MARTINS et al. 2008), even during digestion when an increase in body temperature is thought to be beneficial (ANDRADE et al. 2004). On the other hand, snakes that exhibit a postprandial thermophilic response, such as Pantherophis obsoletus (Say, 1823), are known to bask in open areas more often during digestion than during fasting (Blouin-Demers \& Weatherhead 2001a). Although the habitat of $B$. insularis provides thermoregulatory opportunities for $\mathrm{T}_{\mathrm{b}}$ to be elevated, this possibility would imply shuttling behaviour, which is constrained by the hindered locomotor ability of postprandial snakes (FORD \& SHuttlesworth 1986). Also, since four raptor species, Rupornis magnirostris (Gmelin, 1788) (Accipitridae), Falco peregrinus Tunstall, 1771, Caracara plancus (Miller, 1777), and Milvago chimachima (Vieillot, 1816) (Falconidae) are found on QGI (A. Macarrão, Universidade Estadual Paulista "Júlio de Mesquita Filho", unpubl. data), the exposure of B. insularis in open areas may increase predation risk. Finally, prey consumed by the golden lanceheads - Elaenia mesoleuca (Deppe, 1830) and Turdus flavipes Vieillot, 1818 (Amaral 1921); E. chilensis, and Turdus sp., (A. Macarrão, unpubl. data) - are more abundant inside the lowland forest (O.A.V. Marques and A. Macarrão pers. comm.) and time spent basking in open areas may impair foraging success. In combination, these factors seem to agree with the observation that the postprandial thermophilic response is commonly reported by experimental studies in thermal gradients (WALL \& SHINe 2008). Conversely, in natural conditions, animals face many other constraints and factors besides temperature (e.g. predators, prey availability, climatic factors), and become considerably more elusive. In fact, for the colubrid snake $P$. obsoletus, a postprandial thermophilic response was observed in the laboratory but not clearly in the field (Blouin-Demers \& Weatherhead 2001a).

Thermoregulatory changes associated with reproductive stage are relatively well documented in squamates (BEUCHAT 1986, Charland \& Gregory 1990, Blouin-Demers \& Weatherhead 2001b). Particularly, the elevation and relative stability of $T_{b}$ during gestation have been pointed out as important mechanisms ensuring the proper development of the embryos (Schwarzkopf \& Shine 1991, Brown \& Weatherhead 2000), and, ultimately, improving fitness (Rock et al. 2000). Nonetheless, while this response holds for some snakes species (e.g. BRown $\&$ Weatherhead 2000, Ladyman et al. 2003) including tropical ones (Luiselli \& Akani 2002, Chiaraviglio 2006), it is absent in others (Sanders \& Jacob 1981, IsaAc \& Gregory 2004). For $B$. insularis we found that the $\mathrm{T}_{\mathrm{b}}$ of gravid females conformed to the general relationship between $\mathrm{T}_{\mathrm{b}}$ and $\mathrm{T}_{\mathrm{e}^{\prime}}$ which indicates no change in thermoregulatory behaviour. However, three out of four gravid females were found at temperatures ( $T_{b}$ and $T_{e}$ ) higher than the majority of the individuals (the remaining one being found at night at a considerably colder temperature) (Fig. 2 ). At first glance, this observation could suggest that gravid females selected relatively warmer sites. This idea, however, was not supported by the direct comparison between the $\mathrm{T}_{\mathrm{b}}$ of gravid and non-gravid females found under identical conditions (Fig. 3). Therefore, the reasonable conclusion would be that gestation had no detectable effect on the thermoregulation of free-ranging golden lancehead. Due to our limited sample size, however, such conclusion should be taken with the outmost caution because the power of our statistical test was far below (0.05) the desired level (0.8).

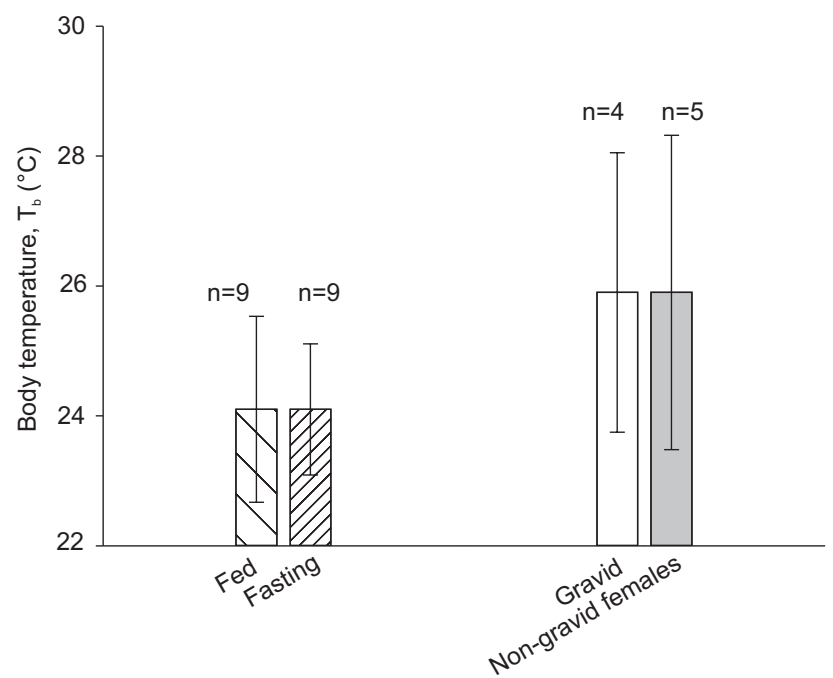

Figure 3. Body temperature comparison between postprandial vs. fasting and gravid vs. non-gravid females of free-ranging golden lanceheads, B. insularis, found under similar conditions. Columns $=$ Mean. Bars $=$ Standard Error.

In summary, we were unable to find any indication that gestation or feeding cause $B$. insularis to modify its thermoregulatory behaviour. We are fully aware that our conclusions rest on a fragile data base formed by the sampling of $T_{b}$ values from a small number of individual snakes. Ideally, long-term body temperature monitoring using radiotelemetry and temperature sensitive implanted devices would provide a more effective way to test for the questions approached here. However, we report on conditions that are infrequently encountered in nature and for which there are few and controversial reports available. This, combined with the fact that fieldwork opportunities at QGI are very limited due to costs and to the inhospitability of the location (AMARAL 1921), prompt us to report the present results. Also, the endemic and insular nature of the golden lancehead, the fact that it is critically endangered (MARQues et al. 2004, MACHADO et al. 2005), and has experienced declining population size in recent years (MarTins et al. 2008), makes it urgent that any biological information about this species be made available. 


\section{ACKNOWLEDGEMENTS}

We are grateful to S.M. Almeida-Santos for discussions about the reproductive biology of snakes, and to G.J. Tattersall and anonymous reviewers for useful suggestions on an earlier draft of the manuscript. We thank QGI research team for help during fieldwork. Procedures were approved by the ICMBioIBAMA (SISBIO license number 16189). This study was supported by grants from the Fundação de Amparo à Pesquisa do Estado de São Paulo (FAPESP) (to RPB, DVA, and OAVM), from the Conselho Nacional de Desenvolvimento Científico e Tecnológico (CNPq) (to DVA), and the Fundação para o Desenvolvimento da Unesp (FUNDUNESP) (to DVA).

\section{LITERATURE CITED}

Amaral, A. 1921. Contribuição para o conhecimento dos ophidios do Brasil. A. Parte II. Biologia da nova espécie, Lachesis insularis. Anexos das Memórias do Instituto Butantan 1: 39-44.

Andrade, D.V. \& A.S. Abe. 1998. Abnormalities in a litter of Boa constrictor amarali. The Snake 28: 28-32.

Andrade, D.V.; A.P. Cruz-neto \& A.S. Abe. 1997. Meal size and specific dynamic action in the rattlesnake, Crotalus durissus (Serpentes, Viperidae). Herpetologica 53 (4): 485-493.

Andrade, D.V.; A.P. Cruz-neto; A.S. Abe \& T. Wang. 2004: Specific Dynamic Action in Ectothermic Vertebrates: a General Review of the Determinants of Post Prandial Metabolic Response in Fishes, Amphibians, and Reptiles, p. 308-324. In: J. M. Starck \& T. WANG (Eds). Physiological and Ecological Adaptations to Feeding in Vertebrates. New Hampshire, Science Publishers, Inc., 425p.

BENEDICT, F.G. 1932. The physiology of large snakes reptiles, with special reference to the heat production of snakes, tortoises, lizards and alligators. Washington, D.C., Carnegie Institution of Washington, Publication 425, 539p.

Beuchat, C.A. 1986. Reproductive influences on the thermoregulatory behaviour of a live bearing lizard. Copeia 1986: 971-979.

Blouin-Demers, G. \& P.J. Weatherhead. 2001a. An experimental test of the link between foraging, habitat selection and thermoregulation in black rat snakes (Elaphe obsoleta obsoleta). Journal of Animal Ecology 70 (6): 1006-1013. doi: 10.1046/j.0021-8790.2001.00554.x.

Blouin-Demers, G. \& P.J. Weatherhead. 2001b. Thermal ecology of black rat snakes (Elaphe obsoleta) in a thermally challenging environment. Ecology 82: 3025-3043. doi: 10.1890/ 0012-9658(2001)082[3025:TEOBRS]2.0.CO;2.

Brown, G.P. \& P.J. Weatherhead. 2000. Thermal ecology and sexual size dimorphism in northern water snakes, Nerodia sipedon. Ecological Monographs 70: 311-330. doi: 10.1890/ 0012-9615(2000)070[0311:TEASSD]2.0.CO;2.

Charland, M.B. \& P.T. Gregory. 1990. The influence of female reproductive status on thermoregulation in a viviparous snake, Crotalus viridis. Copeia 1990: 1089-1098.
Chiaraviglio, M. 2006. The effects of the reproductive condition on thermoregulation in the Argentina Boa Constrictor (Boa constrictor occidentalis) (Boidae). Herpetological Monographs 20: 172-177. doi: 10.1655/0733-1347(2007)20[172: TEORCO]2.0.CO;2.

Ford, N.B. \& G.A. ShUTtLesworth. 1986. Effects of variation in food intake on locomotor performance of juvenile snakes. Copeia 1986: 999-1001.

Fox, W.; C. Gordon \& M.H. Fox. 1961. Morphological effects of low temperatures during embryonic development of the garter snake Thamnophis elegans. Zoologica 46: 57-71.

GarLAND JR, T. \& S.J. ARNOLD. 1983. Effects of a full stomach on locomotory performance of juvenile garter snakes (Thamnophis elegans). Copeia 1983: 1092-1096.

Hutchison, V.H.; H.G. Dowling \& A. Vinegar. 1966. Thermoregulation in a brooding female Indian Python, Python molurus bivittatus. Science 151: 694-696. doi: 10.1126/ science.151.3711.694.

IsAaC, L.A. \& P.T. GRegory. 2004. Thermoregulatory behavior of gravid and non-gravid female grass snakes (Natrix natrix) in a thermally limiting high-latitude environment. Journal of Zoology 264: 403-409. doi: 10.1017/S095283690400593X.

Ladyman, M.; X. Bonnet; O. Lourdais; D. Bradshaw \& G. Naulleau. 2003. Gestation, thermoregulation, and metabolism in a viviparous snake, Vipera aspis: evidence for fecundityindependent costs. Physiological Biochemical Zoology 76 (4): 497-510. doi: 10.1086/376420.

Lillywhite, H. 1987. Temperatures, Energetics and Physiological Ecology, p. 422-477. In: R.A. SEIGEL; R.A. Collins \& S.S. NovAK (Eds). Snakes: Ecology and Evolutionary Biology. New York, McMillan Publ. Co., 529p.

Luiselli, L. \& G.C. Akani. 2002. Is thermoregulation really unimportant for tropical reptiles? Comparative study of four sympatric snake species from Africa. Acta Oecologica 23 (2): 59-68. doi: 10.1016/S1146-609X(02)01134-7.

Lysenko, S. \& J.E. GiLlis. 1980. The effects of ingestive status on the thermoregulatory behavior of Thamnophis sirtalis sirtalis and Thamnophis sirtalis parietalis. Journal of Herpetology 14: 155-159.

Machado, A.B.M.; C.S. Martins \& G.M. Drummond. 2005. Lista da fauna brasileira ameaçada de extinção: Incluindo as espécies quase ameaçadas e deficientes em dados. Fundação Biodiversitas, Belo Horizonte, 160 p.

Marcellini, D.L. \& A. Peters. 1982. Preliminary observations on endogenous heat production after feeding in Python molurus. Journal of Herpetology 16: 92-95.

Marques, O.A.V.; M. Martins \& I. SAZIma. 2004. Bothrops insularis. In: IUCN 2010. IUCN Red List of Threatened Species. Version 2010.1. Available online at: http://www.iucnredlist.org [Accessed:11.VI.2010].

Martins, M.; R.J. SAWAya \& O.A.V. Marques. 2008. A first estimate of the population size of the critically endangered lancehead, Bothrops insularis. South American Journal of Herpetology 
3: $168-174$.

Oliveira, M.E. \& M. Martins. 2001. When and where to find a pitviper: activity patters and habitat use of the lancehead, Bothrops atrox, in Central Amazonia, Brazil. Herpetological Natural Hystory 8: 101-110.

Peel, M.C.; B.L. Finlayson \& T.A. Mcmahon. 2007. Updated world map of the Köppen-Geiger climate classification. Hydrology and Earth System Sciences 11: 1633-1644. doi: 10.5194/ hess-11-1633-2007.

Peterson, C.R.; A.R. Gibson \& M.E. Dorcas. 1993: Snake thermal ecology: the causes and consequences of body-temperature variation, p. 241-314. In: R.A. SEIGel \& J.T. Collins (Ed.). Snakes: Ecology and Behavior. New York, McGraw-Hill, Inc., 414p.

Regal, P.J. 1966. Thermophilic response following feeding in certain reptiles. Copeia 1966: 588-590.

ReinerT, H.K. 1993. Habitat selection in snakes, p. 201-240. In: R.A. Seigel \& J.T. Collins (Eds). Snakes: Ecology and Behavior. New York, McGraw-Hill, Inc., 414p.

Rock, J.; R.M. Andrews \& A. Cree. 2000. Effects of reproductive condition, season, and site on selected temperatures of a viviparous gecko. Physiological Biochemical Zoology 73: 344-355.

Row, J.R. \& G. Blouin-Demers. 2006. Thermal quality influences effectiveness of thermoregulation, habitat use, and behavior in milk snakes. Oecologia 148: 1-11. doi: 10.1007/s00442005-0350-7.

Ruben, J.A. 1976. Aerobic and anaerobic metabolism during activity in snakes. Journal of Comparative Physiology B 109: 147-157. doi: 10.1007/BF00689414.

SANDERS, J.S. \& J.S. JACOB. 1981. Thermal ecology of the copperhead (Agkistrodon contortrix). Herpetologica 37: 264-270.

Schwarzkopf, L. \& R. Shine. 1991. Thermal biology of reproduction in viviparous skinks, Eulamprus tympanum: why do gravid females bask more? Oecologia 88: 562-569. doi: 10.1007/BF00317720.
Sievert, L.M. \& P. Andreadis. 1999. Specific dynamic action and postprandial thermophily in juvenile northern water snakes, Nerodia sipedon. Journal of Thermal Biology 24: 51-55. doi: 10.1016/S0306-4565(98)00037-0.

Stevenson, R.D.; C.R. Peterson \& J.S. Tsuji. 1985. Thermal dependence of locomotion, tongue flicking, digestion, and oxygen consumption in the wandering garter snake. Physiological Zoology 58: 46-57.

Tattersall, G.J.; W.K. Milsom; A.S. Abe; S.P. Brito \& D.V. Andrade. 2004. The thermogenesis of digestion in rattlesnakes. Journal of Experimental Biology 207: 579-585. doi: 10.1242/jeb.00790

Touzeau, T. \& L.M. Sievert, 1993. Postprandial thermophily in rough green snakes (Opheodrys aestivus). Copeia 1993: 11741176.

Van Damme, R.; D. Bauwens \& F. Verheyen. 1991. The thermal dependence of feeding behavior, food consumption and gutpassage time in the lizard Lacerta vivipara Jacquin. Functional Ecology 5: 507-517.

VAN Mierop, L.H.S. \& S.M. BARNARD. 1976. Thermoregulation in a brooding female Python molurus bivittatus (Serpentes: Boidae). Copeia 1976: 398-401.

WALL, M. \& R. SHINe. 2008. Post-feeding thermophily in lizards (Lialis burtonis Gray, Pygopodidae): laboratory studies can provide misleading results. Journal of Thermal Biology 33: 274-279. doi:10.1016/j.jtherbio.2008.02.005.

Wang, T.; M. Busk \& J. Overganid. 2001. The respiratory consequences of feeding in amphibians and reptiles. Comparative Biochemistry and Physiology A 128: 535-549. doi:10.1016/S1095-6433(00)00334-2.

Wang, T.; M. ZaAr; S. Arvedsen; C. Vedel-Smith \& J. Overgaard. 2002. Effects of temperature on the metabolic response to feeding in Python molurus. Comparative Biochemistry and Physiology A 133: 519-527. doi:10.1016/S1095-6433(02)00250-7.

ZAR, J.H. 1996. Biostatistical Analysis. New Jersey, PrenticeHall, $3^{\text {rd }}$ ed., $718 p$.

Submitted: 11.VI.2010; Accepted: 26.IX.2010.

Editorial responsibility: Carolina Arruda Freire

ZOOLOGIA 27 (6): 973-978, December, 2010 